\title{
WHIMBRELS IN THE TABER AREA
}

\section{LLOYD BENNETT, Box 4725, Taber, AB. T1G 2E1}

In most of Alberta, the Whimbrel is a very rarely seen spring migrant. Salt and Salt state that "very few Whimbrels migrate through the interior, and records in the Prairie Provinces are usually sightings of singles or small groups." 1 Peterson reported that Whimbrels are "sparse on the Canadian Plains."

Whimbrels are known to breed in two disjunct areas of North America. One area is along the western coast of Hudson Bay, and the other is the northwestern Mackenzie, northwestern Yukon, and northeastern Alaska. ${ }^{3}$ The main migration routes are said to be along the coasts, with only small numbers travelling inland. ${ }^{3}$ They are highly anticipated by many Alberta birders each year but rarely seen except by a lucky few. However, in the Taber, Alberta area, about $50 \mathrm{~km}$ east of Lethbridge, they can be quite common birds for a short period.

In my 16 years of observations since 1980, Whimbrels have never failed to appear by early May near Taber and flocks can always be found. In fact, their arrival is quite predictable. All first sightings these years were usually single birds or small groups and have been in the period between 27 April and 5 May, with the majority coming between 1 and 4 May. During the second and third weeks of May sightings become more frequent, sometimes almost daily, and the numbers increase as well. A few stragglers are sometimes found the last week of May.

The year that I "discovered" Whim- brels in the Taber area was 1980. Just a few months earlier I had become serious about birds, struggling to learn about them with only the help of field guides. I lived on a farm, and carried binoculars with me whenever possible while working, in order not to miss anything. The first day that I positively identified Whimbrels was 3 May. I had been working on a tractor in the field when a flock of 13 large shorebirds landed not far away in the freshly worked soil.and later walked into a field of short alfalfa. My first thought was that they were Long-billed Curlews because their curved bills were quite apparent. However, upon closer examination with binoculars, I saw that their bills were only about $10 \mathrm{~cm}$ long and the birds were smaller and grayer than Long-billed Curlews. I was familiar with curlews since I saw them frequently in the prairie areas near Taber, so I guessed that these unfamiliar birds were related to them. At home, a search in my field guide revealed that these were Whimbrels. I then realized that on 1 May I had seen five Whimbrels flying over a field but, without close inspection, had assumed them to be Marbled Godwits. During the next few days I had many more sightings of Whimbrels and learned a great deal about their calls, description, and behaviour.

Whimbrels are large shorebirds, about the size of Marbled Godwits. The most obvious field mark is the bill, decurved as in the Long-billed Curlew but much shorter, about 10 $\mathrm{cm}$ long. Much of the body is a mottled brownish gray with the neck and 


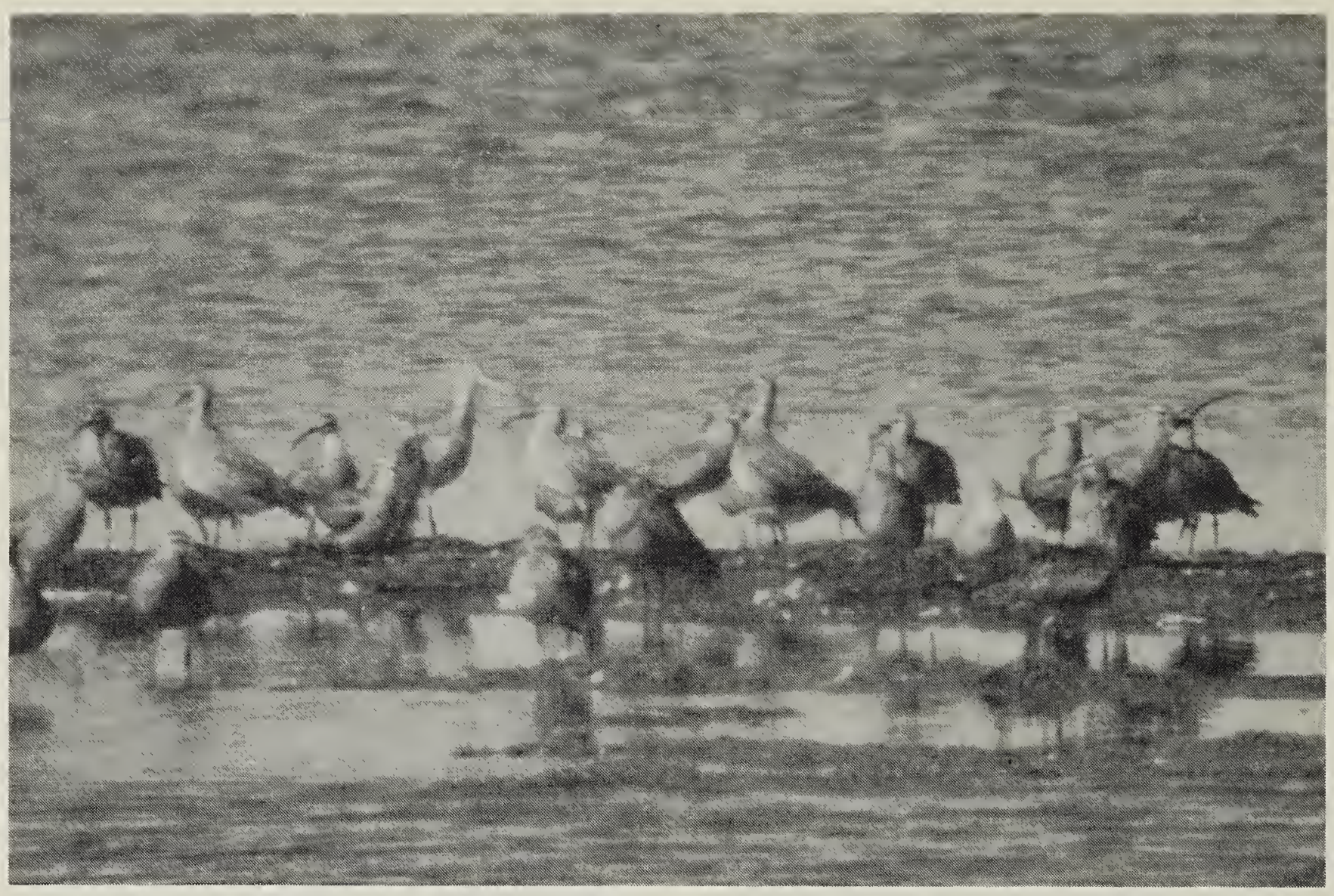

breast lighter than the back and wings and the belly is whitish. Another field mark is the two dark stripes on the crown which are divided by a thin, light median line with another light stripe just over the eye. Another dark stripe passes through the eye from the bill. The legs are bluish gray and the bill is black.

Whimbrels are quite loud and vocal during spring migration, with three distinguishable calls, all of which are somewhat similar to calls of the Long-billed Curlew. One is a short "wititi," all syllables with an upward inflection. A second longer call is a trumpeting "tititititi" which drops slightly in pitch and the third begins with a low bubbling call for about a second, building into a repetition of "tititititi" again.

Whimbrels become common birds in the Taber area during the first half of May and occasional after that as shown in Table 1. In other years, following 1980, records of Whimbrels have had a similar pattern of occurrence.
Table 2 shows the fairly regular arrival dates along with the less regular latest spring dates. The latest spring date is 6 June 1980 and I have no fall records. The numbers vary considerably from year to year but Table 2 shows that the lowest maximum number seen has been between 30 and 35 on four occasions but most years there are many more. The number of days of sightings per year varies from 3 to 16 but I suspect that the low numbers reflect my lack of daily record-keeping of common birds in those years and not a lack of Whimbrels. Be that as it may, it is apparent that there is a significant spring movement of Whimbrels annually in the Taber area.

If so many Whimbrels move through the Taber area each spring, where do they go from there and why are more not recorded in other areas of Alberta? For example, in the Calgary area they are not seen every year and one or two birds is considered to be a typical number (R. Dickson and P. Sherrington, pers. comm.) 


\begin{tabular}{|l|c|l||}
\hline \multicolumn{3}{|c|}{ Table 1: WHIMBREL SIGHTINGS IN THE TABER AREA SPRING 1980 } \\
\hline Date & Number & \multicolumn{1}{|c|}{ Comments } \\
\hline 1 May & 5 & flock in flight over field \\
\hline 3 May & 13 & in ploughed field or short alfalfa \\
\hline 5 May & 20 & in same field \\
\hline 6 May & 28 & groups of 11,9 , and 8 in same field \\
\hline 7 May & 17 & groups of 6 and 11 in same field \\
\hline 8 May & 48 & groups of 5 and 13 in same field, flock of 30 in flight over field \\
\hline 9 May & 11 & in flight over field \\
\hline 10 May & 1 & in flight over field \\
\hline 11 May & 12 & single and group of 11 in fields \\
\hline 12 May & 3 & single and group of 2 in alfalfa \\
\hline 13 May & 1 & in alfalfa \\
\hline 14 May & 2 & two singles in fields \\
\hline 15 May & 2 & 1 in field, 1 in flight over field \\
\hline 23 May & 5 & 1 in field, 4 in flight over field \\
\hline 28 May & 3 & singles in flight \\
\hline 6 June & 1 & in flight \\
\hline
\end{tabular}

although a group of 37 was found just southeast of the city on 16 May 1987 (D. Collister, pers. comm.). There are very few records from the Medicine Hat area (D. Baresco, pers. comm.). In the Lethbridge area, individuals or small groups of up to 5 or 10 birds are found most years (L. Saunders, pers. comm.). Occasionally, large flocks have occurred. Seventy-one were found near Monarch on 12 May 1995 (L. Saunders, pers. comm.) and an impressive 150 were seen at Keho Lake on 13 May 1990 (T. and D. Dolman, pers. comm.).

Whimbrels were sighted in Alberta in only three years from 1961 to 1970, all from Beaverhill Lake, with the largest number 24 birds. ${ }^{4}$ Many more records occurred from 1971 to 1980 from a variety of locations although numbers were generally small. Whimbrels were found in spring between 5 May and 4 June and Alberta's first fall record was reported from the Fort McMurray area with a single bird on 24 August $1980 .{ }^{5}$ Also in this decade the record for the highest number in Alberta was set near Raymond, southeast of
Lethbridge. On 13 May 1979 a flock of 264 birds was found in a field of flooded stubble and alfalfa and 25 were found earlier the same day at Stirling Lake, which is a few miles to the east (A.R. Smith, pers. comm.).

A search of available literature reveals that Whimbrels are not found at any one location in Alberta on a regular basis, with the possible exception of Beaverhill Lake which may have small numbers every year. Therefore, the regular Taber sightings are significant but a mystery as to why they occur. One possible explanation is that the Taber area is a staging area for Whimbrels. Some other shorebirds are known to congregate in large numbers in certain locations, while very few are seen in other areas. An example in Alberta is the Buff-breasted Sandpiper, which stages on the western side of Beaverhill Lake annually, while records from other areas of the province are extremely rare (Ross Dickson, pers. comm.). Whimbrels are strong fliers and could conceivably fly long distances without stopping after leaving Taber, which might 


\begin{tabular}{|c|c|c|c|c|}
\hline Table 2: WHIMBREL SIGHTINGS IN SOUTHERN ALBERTA 1980-1995 \\
\hline Year & Earliest & Latest & Maximum & Days Sighted \\
\hline 1980 & 1 May & 6 June & 48 & 16 \\
\hline 1981 & 27 April & 18 May & 35 & 6 \\
\hline 1982 & 4 May & 19 May & 50 & 12 \\
\hline 1983 & 4 May & 1 June & 100 & 14 \\
\hline 1984 & 3 May & 29 May & 40 & 7 \\
\hline 1985 & 1 May & 23 May & 150 & 5 \\
\hline 1986 & 1 May & 15 May & 30 & 4 \\
\hline 1987 & 1 May & 25 May & 33 & 6 \\
\hline 1988 & 30 April & 21 May & 30 & 4 \\
\hline 1989 & 4 May & 23 May & 110 & 5 \\
\hline 1990 & 3 May & 27 May & 40 & 5 \\
\hline 1991 & 5 May & 15 May & 60 & 3 \\
\hline 1992 & 30 April & 16 May & 85 & 13 \\
\hline 1993 & 27 April & 21 May & 65 & 16 \\
\hline 1994 & 27 April & 16 May & 160 & 6 \\
\hline 1995 & 2 May & 24 May & 215 & 10 \\
\hline
\end{tabular}

explain the lack of records in other areas.

Another possibility is that Whimbrels are travelling mainly in areas not frequented by birders, in farmland and not at lakes. The great majority of records from the Taber area are from farmland, usually freshly worked soil or short alfalfa and sometimes at puddles in fields. Here they appear to be feeding on worms and some insects such as grasshoppers and beetles. Only rarely are they found at lakeshores or sloughs. An exception to this came in 1995 when on 14 May I found about 140 Whimbrels at Scope Lake east of Vauxhall and about 30 at Lake Newell, plus 13 at Lost Lake west of Vauxhall on 16 May. These flocks were on small bars or islands in the company of other shorebirds such as Black-bellied Plovers, Marbled Godwits, and a few Red Knots.

It is my feeling that more Whimbrels should be found across Alberta than have been in the past. Perhaps more observers need to be more aware of their description, habitat preferences, behaviour, and calls. The best ways of finding Whimbrels are by hearing their loud distinctive calls and by watching for these large shorebirds which most often fly in line formation. The best time to look for them is May; starting in early May in southern Alberta and mid to late May in areas farther north. Seeing and hearing a large flock of Whimbrels would be a memorable experience for anyone.

Acknowledgements $\mathrm{H}$. Loney Dickson and Gerry Beyersbergen of the Canadian Wildlife Service provided encouragement and data. Ross Dickson, also of Canadian Wildlife Service, assisted greatly with the literature search and commented on a previous draft of this article. I also wish to thank the following people who shared their records of Whimbrel sightings with me: Teresa and Doug Dolman and Liz Saunders (Lethbridge), Peter Sherrington, Doug Collister and Ross Dickson (Calgary area), Dennis Baresco (Medicine Hat) and Alan R. Smith (Saskatoon). 
1. SALT, W.R. and J.R. SALT. 1976. The birds of Alberta. Hurtig Publishers, Edmonton. 498 pp.

2. PETERSON, R.T. 1961. A field guide to western birds. Houghton Mifflin Company, Boston. 366 pp.

3. GODFREY, W.E. 1986. The birds of Canada, revised edition. National Museum of Canada, Ottawa. 594 pp.

4. SADLER, T.S. and M.T. MYRES.
1976. Alberta birds, 1961-1970. Natural History Occasional Paper No.1, Provincial Museum of Alberta. Edmonton. 314 pp.

5. PINEL, H.W., W.W. SMITH, and C.R. WERSHLER. 1991. Alberta birds, 1971-1980. Natural History Occasional Paper No.13, Vol.1. Provincial Museum of Alberta, Edmonton. 243 pp. Federation of Alberta Naturalists, Edmonton.

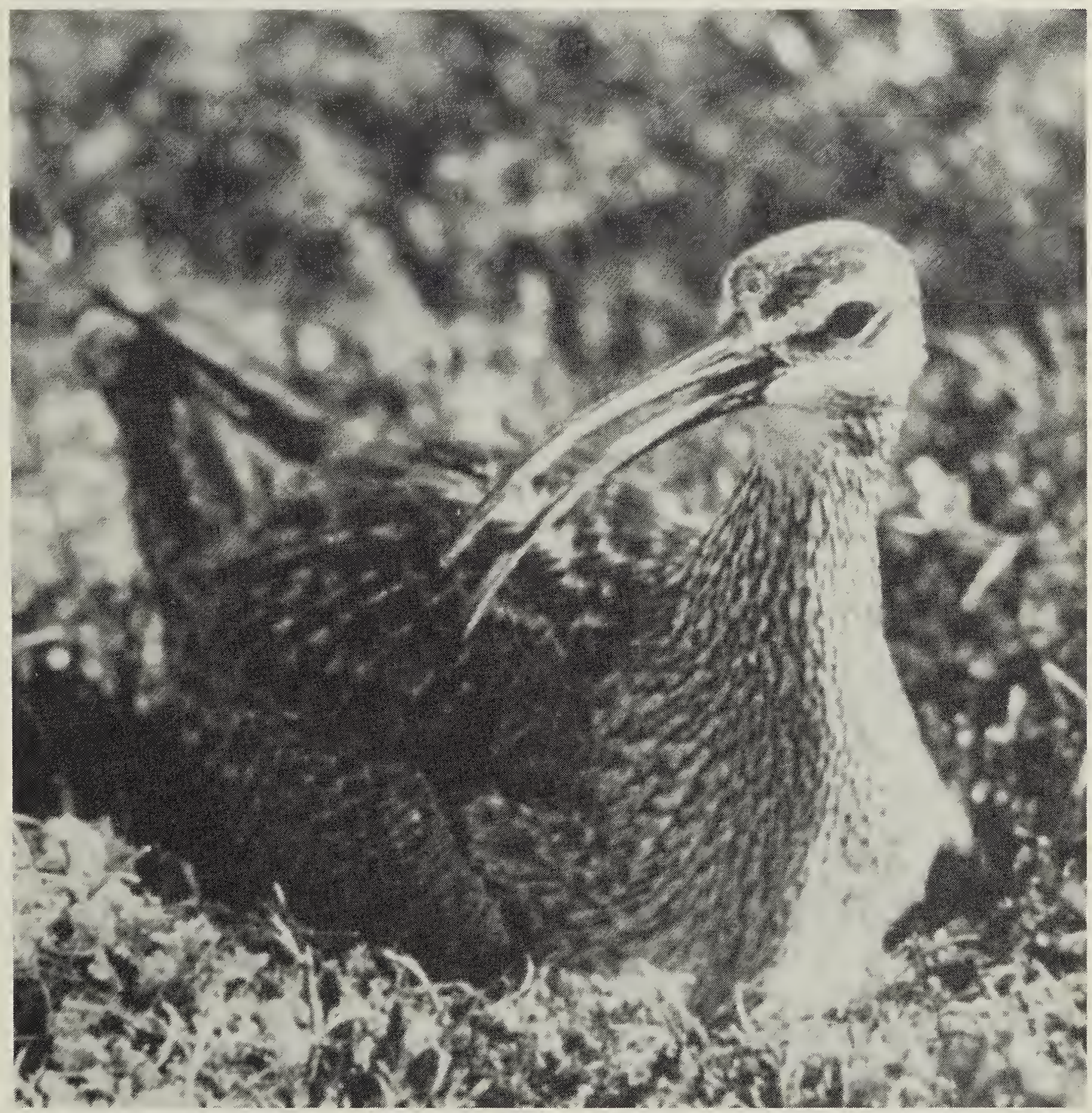

Whimbrel

Wayne Lynch 